\title{
KAJIAN ADSORPSI HORMON PENGATUR TUMBUH ASAM GIBERELIN DENGAN MENGGUNAKAN BENTONIT ALAM
}

\section{SELF-ASSESSMENT OF GROWTH HORMONE ADSORPTION GIBBERELLIN ACID USING NATURAL BENTONITE}

\author{
Ula Nurul Fadlilah, Irwan Nugraha \\ Prodi Kimia Fakultas Sains dan Teknologi Universitas Islam Negeri Sunan Kalijaga \\ Yogyakarta, Jl. Marsda Adisucipto Yogyakarta 55281
}

\begin{abstract}
ABSTRAK
Telah dilakukan adsorpsi asam giberelin dengan menggunakan bentonit alam hasil purifikasi. Proses purifikasi dilakukan dengan menggunakan larutan $\mathrm{H}_{2} \mathrm{O}_{2}$. Bentonit alam hasil purifikasi dikarakterisasi dengan Fourier Transform infrared (FTIR) dan X-Ray difraction (XRD). Jumlah asam giberelin yang teradsorpsi diukur dengan menggunakan spektrofotometer UV-vis. Proses adsorpsi dilakukan dengan sistem batch dan variasi $\mathrm{pH}$ larutan asam giberelin, variasi waktu adsorpsi, variasi kadar bentonit alam serta variasi konsentrasi asam giberelindilakukan untuk mengetahui kapasitas adsorpsi $\mathrm{GA}_{3}$. Hasil penelitian menunjukkan bahwa bentonit alam dapat mengadsorpsi asam giberelin pada $\mathrm{pH}$ larutan asam giberelin optimum pada $\mathrm{pH} 3$, waktu optimum adsorpsi pada 2 jam, kadar bentonit alam pada 1,5 gram dan konsentrasi optimum asam giberelin pada $70 \mathrm{ppm}$. Model isoterm adsorpsi $\mathrm{GA}_{3}$ mengikuti model isoterm Freundlich.
\end{abstract}

Kata kunci : Bentonit, Adsorpsi, Asam Giberelin.

\begin{abstract}
Adsorption of gibberellic acid $\left(\mathrm{GA}_{3}\right)$ onto purified natural bentonite was investigated in this study. Purification process was done by hydrogen peroxide $\left(\mathrm{H}_{2} \mathrm{O}_{2}\right)$. Purified natural bentonite sample was characterized by Fourier Transform infrared (FTIR) and X-Ray difraction (XRD). The amount of $\mathrm{GA}_{3}$ adsorbed was determined by UV spectrophotometer. The adsorption process was carried out in a batch system and the effect of $\mathrm{pH}$, contact time, bentonite content and $\mathrm{GA}_{3}$ concentration were experimentally studied to evaluate the adsorption capacity. The results showed that the optimum adsorption took place at $\mathrm{pH} 3$, contact time for $2 \mathrm{~h}$, bentonite contentat 1,5 gram and $\mathrm{GA}_{3}$ concentration at $70 \mathrm{ppm}$. Adsorption of $\mathrm{GA}_{3}$ followed the Freundlich adsorption isotherm model.
\end{abstract}

Keywords : bentonite, adsorption, gibberellic acid.

\section{PENDAHULUAN}

Pemanfaatan material dalam kaitannya dengan kemampuan untuk adsorpsi dan imobilisasi bahan organik termasuk enzim, protein, hormon, obatobatan serta bakteri saat ini semakin meluas (Joshi et. al, 2007). Penggunaaan slow-release material dalam bidang pertanian dengan berbagai material pengemban telah banyak dilakukan, hal ini dilakukan dalam rangka untuk meningkatkan hasil pertanian serta mengurangi penggunaan bahan kimia yang cenderung dapat mengakibatkan dampak yang buruk bagi manusia serta 
lingkungan (Prihadi, 2005). Tujuan dari penelitian ini adalah untuk mengetahui keadaan optimum adsorpsi bentonit alam terhadap asam giberelin, serta mengatahui model interaksi yang terjadi pada proses adsorpsi tersebut.

Zat pengatur tumbuh yang banyak digunakan dalam bidang pertanian adalah : auksin, giberelin dan sitokinin. Asam giberelin atau yang biasa disebut $\mathrm{GA}_{3}$ merupakan salah satu zat pengatur tumbuh tumbuhan yang sangat berpengaruh terhadap sifat genetik, pembungaan, penyinaran, mobilisasi karbohidrat selama perkecambahan (germination) dan aspek fisiologi lainnya (Abidin, 1993).

Pemanfaatan material pengemban untuk mengimobilisasi zat pengatur tumbuh (ZPT) disatu sisi dapat meningkatkan efektivitas penggunaan ZPT dan disisi lain dapat mempertahankan stabilitas senyawa sehingga aktivitasnya dapat dipertahankan. Beberapa peneliti menunjukkan bahwa hampir semua nutrisi esensial tumbuhan seperti nitrogen, kalium, fosfor dapat disediakan dalam bentuk terikat dengan material zeolit dan lempung (Lai and Ebert, 1986). Material lempung dan zeolit terdapat secara bebas di alam dalam jumlah yang melimpah, namun penggunaanya dalam industri masih tergolong rendah. Pada penelitian ini digunakan mineral lempung, karena lempung merupakan adsorben yang sangat kuat dengan luas permukaan yang sangat besar sehingga lebih efektif apabila digunakan sebagai adsorben. Salah satu ciri partikel tanah liat adalah mempunyai muatan ion positif yang dapat dipertukarkan. Material ini mempunyai daya serap dengan berubahnya kadar kelembapan. Tanah liat mempunyai luas permukaan yang sangat besar(Mahida, 1984).

Lempung digunakan sebagai
slow-release material yang dapat

diaplikasikan dalam bidang pertanian dengan mengembankan asam giberelin $\left(\mathrm{GA}_{3}\right)$ pada lempung tersebut melalui proses adsorpsi. Proses adsorpsi menyebabkan $\mathrm{GA}_{3}$ teradsorp dan menempel pada pori-pori lempung dengan ikatan yang lemah sehingga ikatan tersebut mudah lepas. Dengan lemahnya ikatan tersebut memudahkan penyerapan $\mathrm{GA}_{3}$ oleh tumbuhan, akan tetapi proses pelepasan $\mathrm{GA}_{3}$ tersebut bertahap sehingga lebih ramah lingkungan karena $\mathrm{GA}_{3}$ diasumsikan tidak terbuang di lingkungan.

\section{METODE PENELITIAN}

\section{Bahan dan Alat}

Bahan yang digunakan dalam penelitian ini adalah lempung $\mathrm{Na}-$ bentonit, kristal $\mathrm{GA}_{3}, \mathrm{NaOH} 0,1 \mathrm{M}, \mathrm{HCl}$ 0,1 M, etanol, akuades, akuabides, $\mathrm{H}_{2} \mathrm{O}_{2}$.

Alat yang digunakan adalah seperangkat alat gelas standar, pipet volume, bola hisap,kertas saring whatman milipori ukuran 45, ayakan, pengaduk kaca,timbangan analitik, kompor listrik, magnetic stirrer, $\mathrm{pH}$ meter, pompa vakum, sentrifugasi, satu set alat spektrofotometer UV-vis, spektrofotometer Fourier Transform infrared dan X-Ray difraction.

\section{Prosedur Penelitian}

\section{Pencucian Bentonit Alam}

Bentonit alam sebanyak 100 gram dilarutkan kedalam $1000 \mathrm{ml}$ akuades dan diaduk sampai homogen. Larutan ditambah dengan $\pm 400 \mathrm{ml}$ peroksida $\left(\mathrm{H}_{2} \mathrm{O}_{2}\right)$. Kemudian di diamkan selama 24 jam dan ditambahkan akuades untuk selanjutnya di keringkan dalam oven pada suhu $110{ }^{\circ} \mathrm{C}$. Pencucian dilakukan sampai 4 kali. Bentonit yang telah kering dihaluskan dengan lumpang porselen sampai halus. Selanjutnya bentonit alam hasil purifikasi dikarakterisasi dengan 
menggunakan spektrofotometer Fourier Transform infrared dan X-Ray difraction.

\section{Uji Adsorpsi Asam Giberelin}

Variasi pH pada konsentrasi 50 ppm. Lima sampel bentonit sebanyak 0,5 gram ditambahkan ke dalam larutan $\mathrm{GA}_{3}$ dengan konsentrasi $50 \mathrm{ppm}$ dengan $\mathrm{pH}$ awal diatur pada $\mathrm{pH} 2 ; 3 ; 4 ; 5$ dan 6 menggunakan $0,1 \mathrm{M} \mathrm{HCl}$ dan $0,1 \mathrm{M}$ $\mathrm{NaOH}$. Proses adsorpsi dilakukan dengan menggunakan magnetic stirrer selama 3 jam. Selanjutnya disaring dan filtrat dianalisa dengan spektrofotometer UVvis.

Variasi waktu pada konsentrasi 50 ppm. Lima sampel bentonit sebanyak 0,5 gram ditambahkan ke dalam larutan $\mathrm{GA}_{3}$ dengan konsentrasi $50 \mathrm{ppm}$ pada $\mathrm{pH}$ optimum hasil variasi $\mathrm{pH}$. Proses adsorpsi dilakukan dengan menggunakan magnetic stirrer selama 30, 60, 90, 120, 180 dan 300 menit. Selanjutnya disaring dan filtrat dianalisa dengan spektrofotometer UV-vis.

Variasi kadar benonit alam. Lima sampel bentonit sebanyak 0,$5 ; 0,75$; $1 ; 1,25$ dan 1,5 gram, masing-masing ditambahkan ke dalam larutan $\mathrm{GA}_{3}$ dengan konsentrasi 50 ppm pada $\mathrm{pH}$ optimum hasil variasi $\mathrm{pH}$. Proses adsorpsi dilakukan dengan menggunakan magnetic stirrer selama waktu optimum hasil variasi waktu. Selanjutnya disaring dan filtrat dianalisa dengan spektrofotometer UV-vis.

Variasi Konsentrasi Asam Giberelin. Lima sampel bentonit hasil purifikasi sebanyak 0,5 gram ditambahkan kedalam larutan $\mathrm{GA}_{3}$ dengan variasi konsentrasi 30, 40, 50, 60 dan 70 ppm dengan $\mathrm{pH}$ awal diatur pada $\mathrm{pH}$ optimum hasil variasi $\mathrm{pH}$. Proses pengadukan dilakukan dengan menggunakan magnetic stirrer selama waktu kontak optimum hasil variasi waktu. Selanjutnya filtrat dianalisis dengan UV-Vis.

\section{HASIL DAN PEMBAHASAN}

\section{Pencucian Bentonit Alam}

Bentonit adalah istilah perdagangan untuk sejenis lempung yang banyak mengandung mineral montmorilonit (sekitar $85 \%$ ), sedangkan montmorilonit merupakan mineral lempung berstruktur lapis dengan tipe 2:1(Tan, 1982). Pencucian bentonit bertujuan untuk menghilangkan pengotor organik yang terdapat dalam bentonit. Data spektroskopi FTIR dari sampel yang diperiksa memberikan informasi mengenai jenis vibrasi gugus fungsional pada sampel dan juga menunjukkan keberadaan mineral lain serta adanya mineral- mineral pengotor yang terdapat dalam sampel. Jenis- jenis vibrasi secara kuantitatif menunjukkan struktur bentonit dan tingkat kemurniannya (Sunardi dkk, 2009). Spektra FTIR pada mineral bentonit yaitu montmorillonit akan memberikan puncak pada bilangan gelombang $3100-3700 \mathrm{~cm}^{-1}$ yang merupakan puncak yang terbentuk karena adanya vibrasi ulur O-H dan puncak pada bilangan gelombang 1600-1700 $\mathrm{cm}^{-1}$ merupakan daerah vibrasi tekuk $\mathrm{H}-\mathrm{O}-\mathrm{H}$. Pita serapan yang muncul pada bilangan gelombang 3100-3700 $\mathrm{cm}^{-1}$ dan 1600$1700 \mathrm{~cm}^{-1}$ berasal dari adanya molekul $\mathrm{H}_{2} \mathrm{O}$ yang terikat melalui ikatan hidrogen pada montmorillonit (Anna dkk, 2010).Spektra FTIR bentonit alam hasil purifikasi dapat dilihat pada gambar 1 .

Pada Gambar 1, spektra FTIR bentonit hasil purifikasi terdapat beberapa puncak serapan utama, yaitu pada panjang gelombang 3626; 3448; 1635; $1033 ; 918 ; 794 ; 524 ; 462 \mathrm{~cm}^{-1}$. Bilangan gelombang $1033 \mathrm{~cm}^{-1}$ menunjukkan vibrasi ulur $\mathrm{C}-\mathrm{O}-\mathrm{C}$, bilangan gelombang $1635 \mathrm{~cm}^{-1}$ yang merupakan vibrasi tekuk $\mathrm{H}-\mathrm{O}-\mathrm{H}$ dan bilangan gelombang $3626 \mathrm{~cm}^{-}$ ${ }^{1}$ yang merupakan vibrasi ulur $\mathrm{O}-\mathrm{H}$ pada (Mg-Al)-OH (Anna, 2010). 


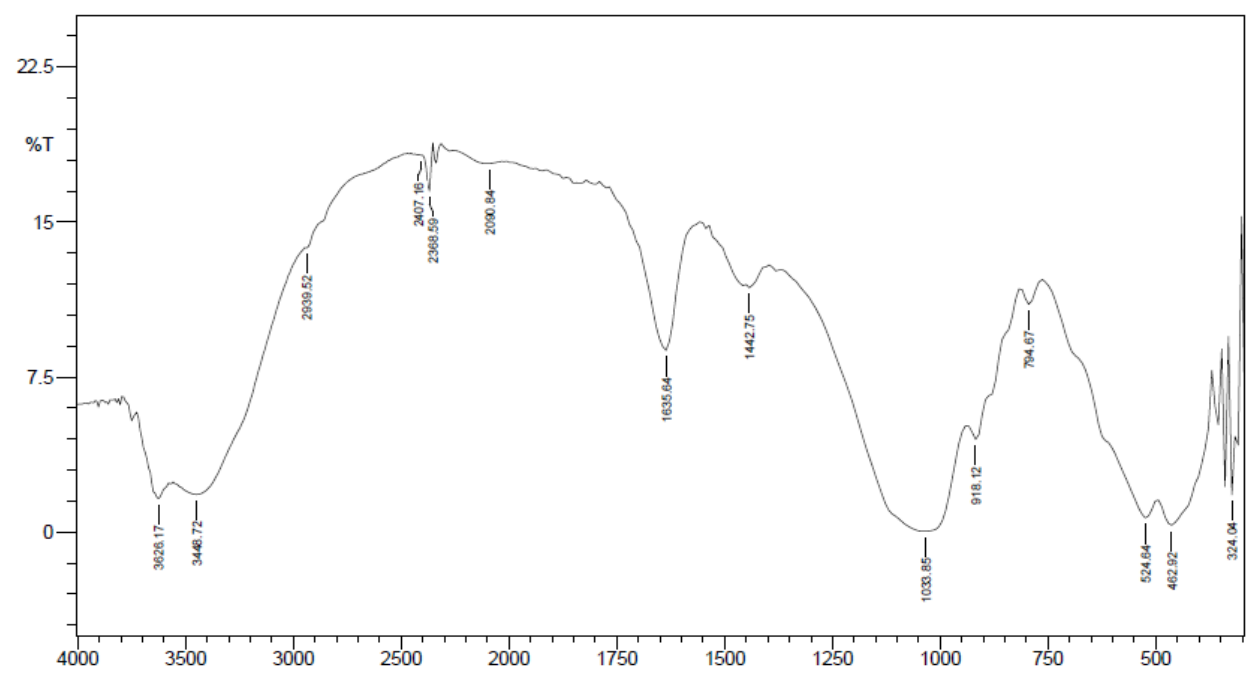

Gambar 1. Spektra FTIR Bentonit Alam hasil purifikasi

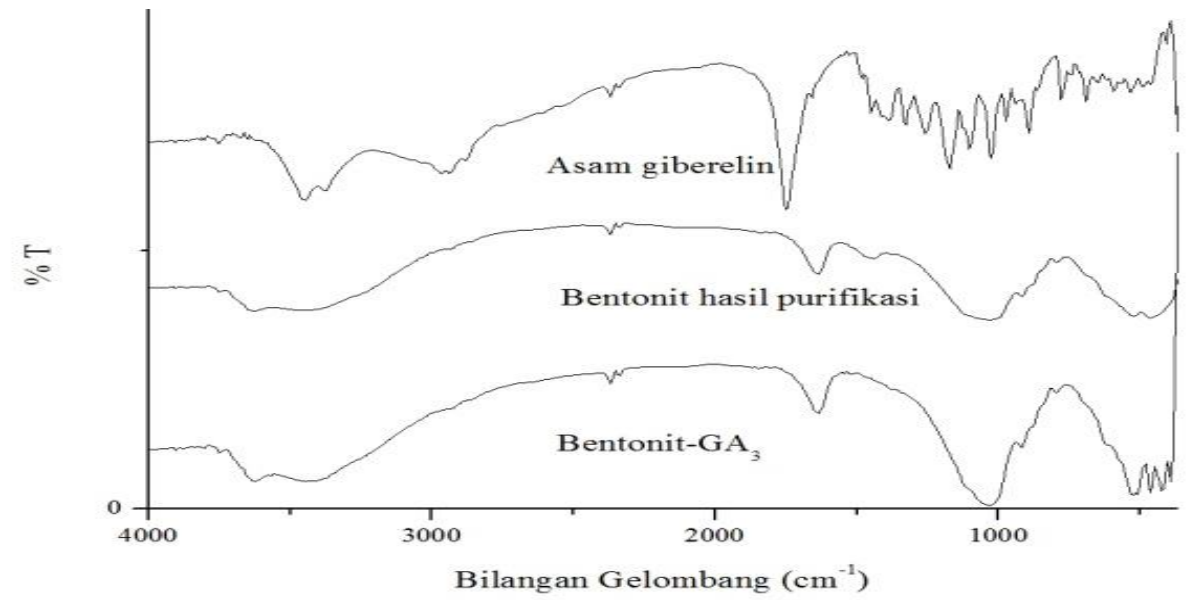

Gambar 2. Spektra FTIR Untuk Bentonit Hasil Purifikasi, Asam Giberelin dan Bentonit setelah dikontakkan dengan $\mathrm{GA}_{3}$

Bilangan gelombang $3448 \mathrm{~cm}^{-1}$ menunjukkan vibrasi ulur $\mathrm{H}-\mathrm{O}-\mathrm{H}$, bilangan gelombang $462 \mathrm{~cm}^{-1}$ menunjukkan vibrasi tekuk $\mathrm{Si}-\mathrm{O}-\mathrm{Si}$, bilangan gelombang $524 \mathrm{~cm}^{-1}$ menunjukkan vibrasi tekuk Si-O-Al atau Si-O-Mg serta bilangan gelombang $794 \mathrm{~cm}^{-1}$ menunjukkan vibrasi ulur Si-O (Rifa'i, 2013). Adapun untuk panjang gelombang $918 \mathrm{~cm}^{-1}$ menunjukkan vibrasi tekuk $\mathrm{OH}$ yang berikatan dengan kation (Konta, 1995). Bilangan gelombang bentonit alam hasil purifikasi disajikan dalam Tabel 1.
Berdasarkan Tabel 1 terlihat bahwa dalam bentonit hasil purifikasi masih terdapat beberapa pengotor, akan tetapi kadarnya lebih rendah. Serta dapat diketahui juga hasil dari purifikasi yang bertujuan untuk menghilangkan pengotor organik yang kemungkinan akan mengganggu proses analisis. Perbandingan spekra FTIR bentonit alam hasil purifikasi, asam giberelin dan bentonit alam setelah adsorpsi dapat dilihat pada Gambar 2. 
Tabel 1. Bilangan Gelombang Bentonit Alam hasil Purifikasi

\begin{tabular}{lll}
\hline No & $\begin{array}{l}\text { Bilangan Gelombang } \\
\left(\mathrm{cm}^{-1}\right)\end{array}$ & Penetapan Pita \\
\hline 1. & 462 & Vibrasi tekuk Si-O-Si \\
2. & 524 & Vibrasi tekuk Si-O-Al/ Si-O-Mg \\
3. & 794 & Vibrasi ulur Si-O \\
4. & 918 & Vibrasi tekuk O-H \\
5. & 1033 & Vibrasi ulur C-O-C \\
6. & 1635 & Vibrasi tekuk H-O-H \\
7. & 3448 & Vibrasi ulur H-O-H \\
8. & 3626 & Vibrasi ulur OH pada $(\mathrm{Mg}-\mathrm{Al})-\mathrm{OH}$ \\
\hline
\end{tabular}

Untuk menguatkan hasil analisis FTIR, dilakukan pengukuran dengan XRD. Berdasarkan hasil pengukuran dengan XRD, bentonit hasil purifikasi menghasilkan base spacing $\mathrm{d}_{001}$ sebesar 14,65 ̊́, sedangkan secara teori Nabentonit memiliki base spacing sebesar 9,80 Á. Hal ini menunjukkan bahwa Nabentonit sedikit mengandung air sehingga sewaktu dilakukan pengukuran didapatkan hasil yang besar. Hasil pengukuran XRD sampel bentonit setelah purifikasi disajikan pada Gambar 3.
Puncak-puncak difraksi setiap mineral lempung adalah khas, sudut difraksi $2 \theta$ berhubungan dengan bidang kisi kristal mineral yang dianalisis (Sunardi, 2009). Berdasarkan difraktogram XRD untuk bentonit hasil purifikasi diketahui bahwa mineral montmorillonit ditunjukkan pada $2 \theta$; 6,02 dan 20,17. Bentonit hasil purifikasi yang digunakan dalam proses adsorpsi masih mengandung mika, kuarsa serta kaolin dengan kadar yang rendah sehingga tidak mengganggu dalam proses adsorpsi.

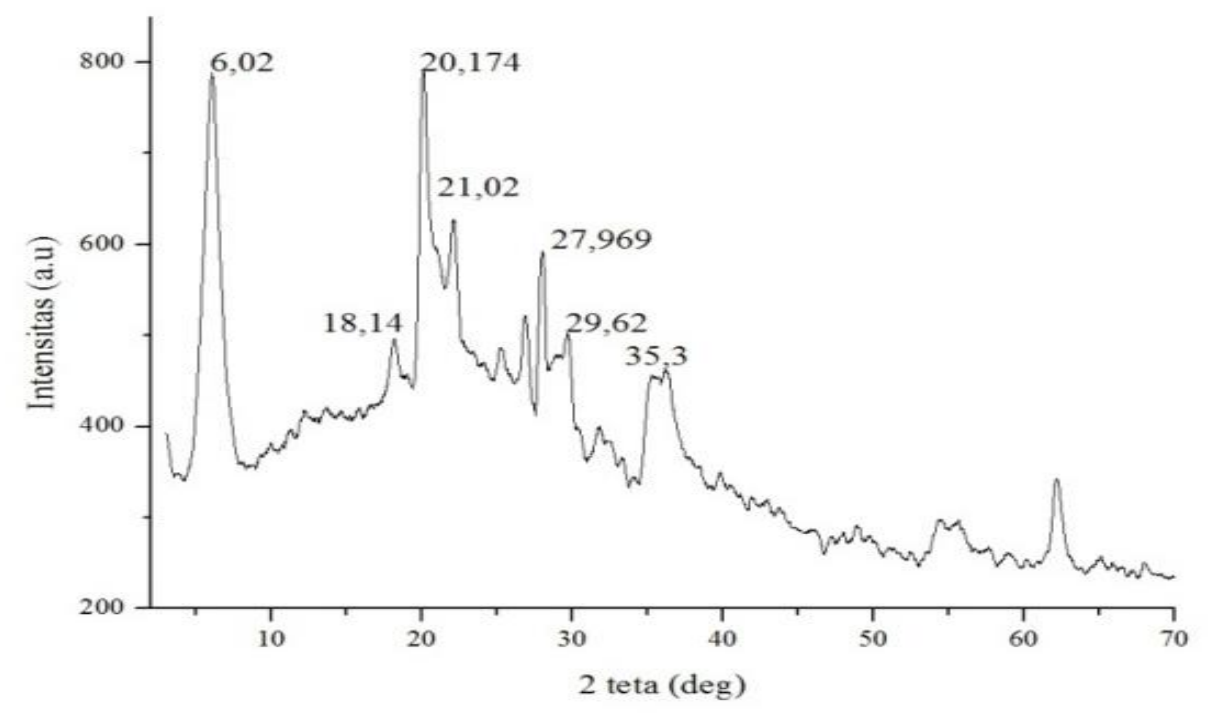

Gambar 3. Difraktogram XRD Bentonit Alam hasil purifikasi. 
Kajian adsorpsi hormon pengatur tumbuh asam... (Ula Nurul F dan Irwan Nugraha)

Tabel 2. Harga $2 \theta$ dan Jenis Mineral Bentonit Alam Hasil purifikasi

\begin{tabular}{ccc}
\hline No & $\mathbf{2 \theta}$ & Mineral \\
\hline 1. & 6,02 & Montmorillonit \\
2. & 18,14 & Mika \\
3. & 20,17 & Montmorillonit \\
4. & 21,02 & Kuarsa \\
5. & 24,10 & Kaolinit \\
6. & 26,85 & Kuarsa \\
7. & 38,32 & Kaolinit \\
\hline
\end{tabular}

\section{Uji Adsorpsi Bentonit terhadap GA 3}

Uji adsorpsi bentonit terhadap asam giberelin $\left(\mathrm{GA}_{3}\right)$ meliputi penetuan keadaan optimum adsorpsi untuk faktor $\mathrm{pH}$, waktu adsorpsi, kadar bentonit dan konsentrasi $\mathrm{GA}_{3}$ yang dapat diketahui dari nilai kapasitas adsorpsi.

Variasi pH. Untuk mengetahui pengaruh $\mathrm{pH}$ pada adsorpsi bentonit terhadap $\mathrm{GA}_{3}$, larutan $\mathrm{GA}_{3}$ dengan konsentrasi $50 \mathrm{ppm}$ diatur dengan $\mathrm{pH}$ yang bervariasi mulai dari $\mathrm{pH} 2$ sampai 6 dengan massa bentonit alam sebesar 0,5 gram. Proses adsorpsi dilakukan dengan waktu kontak selama 3 jam dengan menggunakan magnetic stirrer. Penentuan $\mathrm{pH}$ optimum dilakukan berdasarkan nilai kapasitas adsorpsi $(Q)$. Hasil dapat dilihat pada gambar 4 .

Nilai kapasitas adsorpsi $(Q)$ pada bentonit alam akan naik hingga mencapai titik optimum kemudian menurun. Dari gambar $3 \mathrm{pH}$ optimum terjadi pada $\mathrm{pH} 3$ dengan kapasitas sebesar $0,50625 \mathrm{mg} / \mathrm{g}$. Hal ini dapat diketahui dari nilai $Q$ yang meningkat pada $\mathrm{pH}$ tersebut dan menurun pada $\mathrm{pH}$ 4 sampai 6. Hal ini disebabkan karena $\mathrm{GA}_{3}$ merupakan kelompok senyawa asam organik yang secara teori lebih mudah teradsorpsi pada $\mathrm{pH}$ rendah. Sehingga pada $\mathrm{pH}$ yang lebih tinggi kapasitas adsorpsi bentonit hasil purifikasi cenderung menurun, akan tetapi ketika larutan diatur pada $\mathrm{pH} 2$ kemungkinan terjadi kerusakan struktur pada bentonit alam hasil purifikasi karena lingkungan yang terlalu asam sehingga menyebabkan kapasitas adsorpsinya rendah.

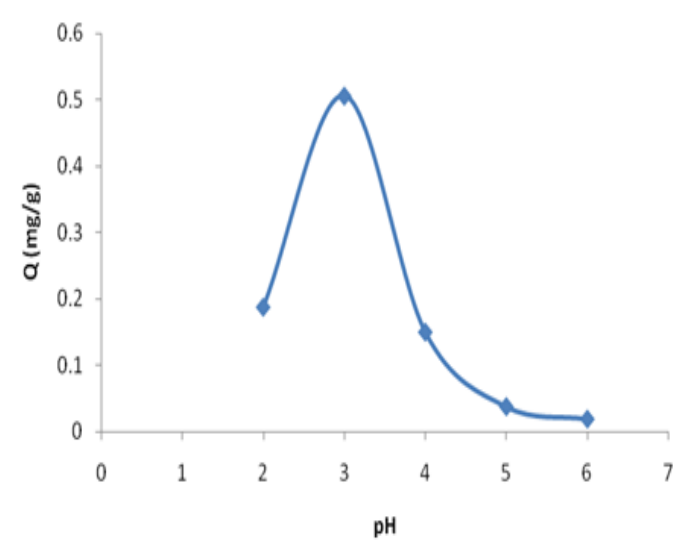

Gambar 4. Hubungan antar $\mathrm{pH}$ dan Kapasitas Adsorbsi Bentonit alam Dengan $\mathrm{GA}_{3}$

Variasi waktu. Penentuan waktu optimum kontak antar $\mathrm{GA}_{3}$ dengan bentonit alam dilakukan pada $\mathrm{pH} 3$ dan konsentrasi $\mathrm{GA}_{3}$ adalah sebesar 50 ppm dan berat adsorben atau bentonit alam sebesar 0,5 gram. Proses adsorpsi dilakukan dengan variasi waktu pengadukan 30, 60, 90, 120, 180 dan 300 menit. Penentuan waktu optimum dilakukan berdasarkan besarnya nilai kapasitas adsorpsi $(Q)$. Nilai kapasitas adsorpsi menunjukkan jumlah $\mathrm{GA}_{3}$ yang terserap dalam bentonit alam. Hasil pengukuran dapat dilihat pada gambar 5 .

Parameter penting lain yang perlu diperhatikan dalam proses adsorpsi adalah penentuan waktu adsorpsi optimum. Waktu adsorpsi berkaitan dengan berapa lama waktu yang dibutuhkan agar $\mathrm{GA}_{3}$ dapat terserap secara optimal oleh bentonit alam. Penentuan waktu optimum dilakukan berdasarkan besarnya nilai kapasitas adsorpsi $(Q)$. Nilai kapasitas adsorpsi menunjukkan jumlah $\mathrm{GA}_{3}$ yang terserap dalam bentonit alam. 


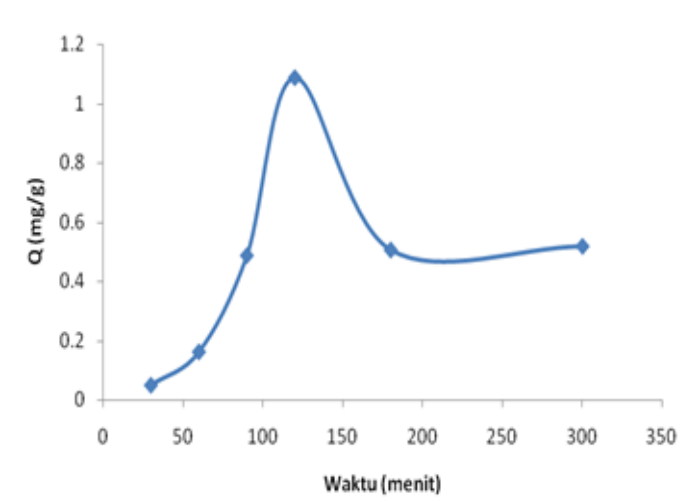

Gambar 5. Hubungan Antara Waktu Adsorpsi dan Kapasitas Adsorpsi Bentonit Alam Dengan $\mathrm{GA}_{3}$

Berdasarkan grafik hubungan antara waktu adsorpsi dengan kapasitas adsorpsi, waktu adsorpsi optimum larutan $\mathrm{GA}_{3}$ dengan bentonit alam terjadi pada waktu 120 menit dengan kapasitas adsorpsi sebesar $1,0875 \mathrm{mg} / \mathrm{g}$. Hal ini dapat dilihat pada grafik dimana nilai $Q$ meningkat pada waktu tersebut dan menurun setelah melewati waktu kesetimbangan. Waktu optimum untuk adsorpsi $\mathrm{GA}_{3}$ terhadap bentonit membutuhkan waktu yang relatif lebih panjang, hal ini disebabkan karena ukuran molekul $\mathrm{GA}_{3}$ yang cukup besar sehingga dibutuhkan waktu yang lebih lama untuk teradsorp ke dalam situs aktif bentonit.

Variasi kadar bentonit. Parameter yang ketiga adalah kadar bentonit. Untuk mengetahui pengaruh kadar bentonit alam terhadap proses adsorbsi $\mathrm{GA}_{3}$, bentonit alam hasil purifikasi divariasikan dengan berat 0,$5 ; 0,75 ; 1$; 1,25 dan 1,5 gram. Bentonit tersebut di kontakkan dengan larutan asam giberelin dengan konsentrasi $50 \mathrm{ppm}$ selama 2 jam, pengadukan dilakukan dengan menggunakan magnetic stirrer serta $\mathrm{pH}$ larutan diatur pada $\mathrm{pH}$ 3. Hasil perhitungan kapasitas adsorpsi bentonit alam terhadap asam giberelin pada variasi kadar bentonit dapat dilihat pada gambar 6.

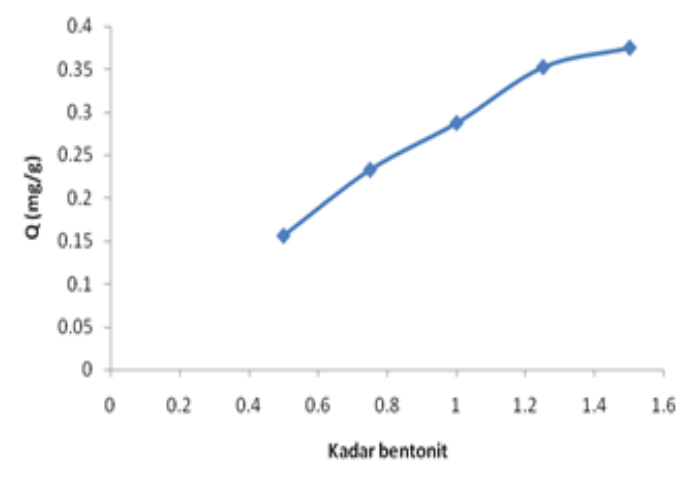

Gambar 6. Hubungan antara Kadar Bentonit dengan kapasitas adsorpsi bentonit alam terhadap $\mathrm{GA}_{3}$

Berdasarkan data hasil pengukuran variasi konsentrasi diketahui bahwa kapasitas adsorpsi maksimum didapatkan ketika berat bentonit sebesar 1,5 gram dengan kapasitas adsorpsi $0,375 \mathrm{mg} / \mathrm{g}$. Dari grafik hasil, menunjukkan kenaikan kapasitas adsorpsi dari kadar bentonit 0,5 sampai 1,5 gram. Hal ini menunjukkan bahwa semakin besar kadar bentonit, maka semakin banyak gugus fungsi bentonit.Sehingga grafik hasil menunjukkan kenaikan nilai kapasitas adsorpsi.

Variasi konsentrasi GA 3. Untuk mengetahui pengaruh konsentrasi asam giberelin terhadap proses adsorbsi dengan bentonit hasil purifikasi, asam giberelin divariasikan konsentrasinya yaitu 30, 40, 50, 60 dan 70 ppm. Asam giberelin tersebut dikontakkan dengan bentonit hasil purifikasi sebanyak 0,5 gram selama 2 jam, pengadukan dilakukan dengan menggunakan magnetic stirrer serta $\mathrm{pH}$ larutan diatur pada $\mathrm{pH} 3$.

Variasi konsentrasi memegang peranan yang penting dalam proses adsorpsi karena pada konsentrasi yang tinggi, asam giberelin akan menghasilkan daya dorong yang tinggi untuk masuk ke dalam situs aktif 
adsorben. Serta variasi konsentrasi asam giberelin digunakan untuk penentuan model isoterm adsorpsi yang terjadi pada saat proses adsorpsi. Hasil perhitungan kapasitas adsorpsi bentonit alam terhadap asam giberelin dapat dilihat pada gambar 7 .

Berdasarkan gambar 7, diperoleh konsentrasi optimum asam giberelin pada konsentrasi 70 ppm dengan kapasitas adsorpsi sebesar 0,45176 mg/g. Dari grafik hasil, menunjukkan kenaikan kapasitas adsorpsi dari konsentrasi 30 ppm samapai dengan $70 \mathrm{ppm}$. Hal ini menunjukkan bahwa semakin besar konsentrasi asam giberelin, maka semakin besar pula gaya dorong (driving force) yang menyebabkan semakin banyak asam giberelin yang teradsorp kedalam bentonit hasil purifikasi. Sehingga grafik hasil menunjukkan kenaikan.

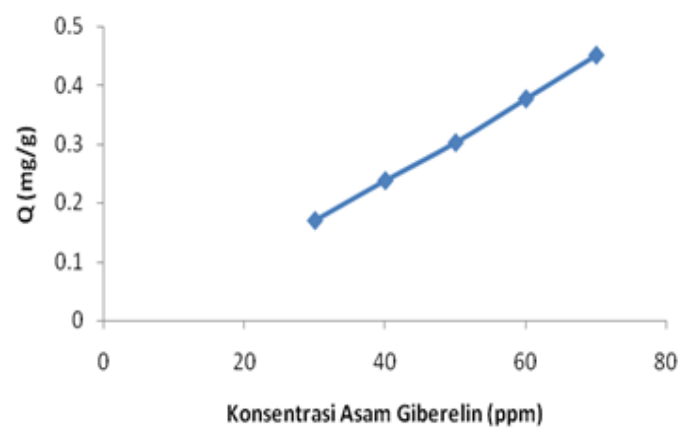

Gambar 7. Hubungan Antara Konsentrasi $\mathrm{GA}_{3}$ dan Kapasitas Adsorpsi Bentonit dengan $\mathrm{GA}_{3}$

Fenomena adsorpsi digambarkan melalui suatu hubungan antara jumlah adsorbat yang terjerap per satuan bobot adsorben dan konsentrasi kesetimbangan. Hubungan ini disebut sebagai isoterm adsorpsi. Telah banyak isoterm adsorpsi yang dikembangkan untuk mendeskripsikan interaksi antara adsorben dan adsorbat. Isoterm Freundlich dan Langmuir pada umumnya dianut oleh adsorpsi padatcair (Atkins, 1999).
Isoterm adsorpsi digunakan untuk mengetahui model interaksi antara adsorben dan adsorbat melalui dua model isoterm, yaitu model isoterm Langmuir dan model isoterm Freundlich. Pola isoterm Langmuir didasarkan pada asumsi bahwa jumlah situs aktif yang dapat berikatan tersebar merata pada permukaan adsorben (struktur adsorben bersifat homogen), dimana situs tersebut cenderung mempunyai afinitas yang sama untuk mengadsorpsi dan membentuk lapisan tunggal (monolayer) (Nandi, 2009). Hasil perhitungan isoterm Langmuirdan Freundlich dapat dilihat pada Tabel 3.

Sedangkan isoterm Freundlich menggambarkan interaksi yang terjadi antara adsorbat dan adsorben didominasi oleh interaksi secara fisik (Tamzil Las,dkk., 2011). Isoterm Freundlich mengasumsikan terjadinya ikatan lemah antara adsorbat dengan adsorben yang hanya melibatkan interaksi Van der Waals yang memiliki energi ikatan yang lemah (Puspitasari,2006). Lemahnya ikatan bentonit alam dengan $\mathrm{GA}_{3}$ disebabkan karena adsorpsi pada permukaan yang heterogen dan bersifat multilayer, yaitu terjadi interaksi pada lapisan kedua dan seterusnya pada bentonit alam dengan $\mathrm{GA}_{3}$. Hal ini menunjukkan bahwa tidak semua permukaan pada lapisan bentonit alam terjadi proses adsorpsi (Puspitasari, 2006).

Berdasarkan hasil penelitian yang ditunjukkan dengan nilai $\mathrm{R}^{2}$ dari kedua model isoterm tersebut. Nilai $\mathrm{R}^{2}$ untuk isoterm Langmuir sebesar 0,906, sedangkan untuk isoterm Freundlich sebesar 0,964. Dari data $\mathrm{R}^{2}$ tersebut sesungguhnya belum dapat dipastikan model isotem Freundlich atau model isoterm Langmuir yang terjadi pada proses adsorpsi $\mathrm{GA}_{3}$ oleh bentonit alam hasil purifikasi. Akan tetapi karena nilai $\mathrm{R}^{2}$ pada isoterm Freundlich lebih 
mendekati 1, ada kemungkinan hasil penelitian ini cenderung mengikuti model isoterm Freundlich.

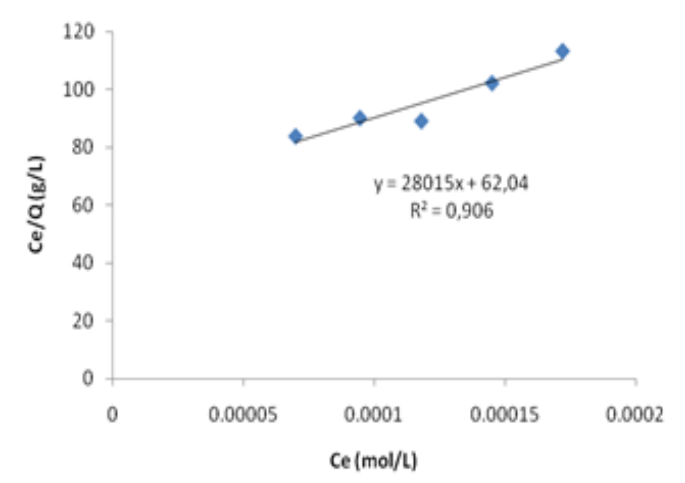

Gambar 8.Grafik Isoterm Langmuir Bentonit Alam Dengan $\mathrm{GA}_{3}(\mathrm{Ce} / \mathrm{Q}(\mathrm{g} / \mathrm{L}) \mathrm{Vs} \mathrm{Ce}(\mathrm{mol} / \mathrm{L}))$

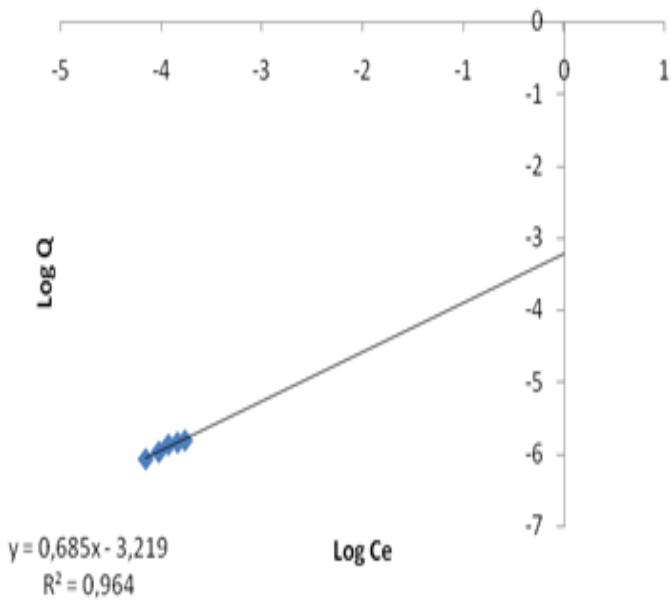

Gambar 9. Grafik Isotherm Freudlich Bentonit Alam Dengan $\mathrm{GA}_{3}$, (Log Q Vs Log Ce)

Tabel 3. Hasil Perhitumgan Isoterm Adsorpsi Langmuir dan Freundlich pada $\mathrm{GA}_{3}$ Dengan Bentonit Alam

\begin{tabular}{ccc}
\hline $\begin{array}{c}\text { Model } \\
\text { Isoterm }\end{array}$ & $\mathrm{R}^{2}$ & Konstanta \\
\hline Langmuir & 0,906 & $\mathrm{~K}=4 \begin{array}{c}4,515 \times 10^{2} \\
\mathrm{~L} / \mathrm{mol}\end{array}$ \\
& & $\mathrm{Kf}=\begin{array}{c}6,039 \times 10^{-4} \\
\mathrm{~L} / \mathrm{mol}\end{array}$ \\
\hline
\end{tabular}

Isoterm

Freundlich menggambarkan interaksi yang terjadi antara adsorbat dan adsorben didominasi oleh interaksi secara fisik (Tamzil Las,dkk., 2011). Hal ini didukung dengan hasil perhitungan energi adsorpsi $\mathrm{GA}_{3}$ dengan bentonit alam, yaitu sebesar $18,619 \mathrm{KJ} / \mathrm{mol}$. Serta hasil pengukuran spektra FTIR pada bentonit yang telah dikontakkan dengan asam giberelin.

Berdasarkan gambar 2, dapat diketahui bahwa tidak terjadi perubahan spektra yang signifikan. Hal ini membuktikan bahwa tidak etrjadi ikatan kimia antara bentonit dan asam giberelin. Ikatan yang terjadi pada proses adsorpsi ini adalah ikatan Van der Waals dari situs aktif $\mathrm{GA}_{3}$ dan permukaan bentonit. Ikatan Van der Waals memiliki energi yang rendah sehingga ikatannya relatif lemah. Lemahnya ikatan tersebut akan memudahkan proses desorpsi $\mathrm{GA}_{3}$.

\section{KESIMPULAN}

Berdasarkan penelitian yang telah dilakukan, maka dapat diambil kesimpulan sebagai berikut :

1) Bentonit alam hasil purifikasi dapat mengadsorpsi $\mathrm{GA}_{3}$ pada $\mathrm{pH}$ optimum 3 dengan kapasitas adsorpsi sebesar 0,50625 mg/g.

2) Bentonit alam hasil purifikasi dapat mengadsorpsi $\mathrm{GA}_{3}$ pada waktu adsorpsi optimum selama 2 jam dengan kapasitas adsorpsi sebesar $1,0875 \mathrm{mg} / \mathrm{g}$.

3) Bentonit alam hasil purifikasi dapat mengadsorpsi $\mathrm{GA}_{3}$ pada kadar bentonit sebesar 1,5 gram dengan kapasitas adsorpsi 0,90625 mg/g.

4) Bentonit alam hasil purifikasi dapat mengadsorpsi $\mathrm{GA}_{3}$ pada konsentrasi optimum pada konsentrasi 70 ppm dengan kapasitas adsorpsi 0,45175 $\mathrm{mg} / \mathrm{g}$. 
Kajian adsorpsi hormon pengatur tumbuh asam... (Ula Nurul F dan Irwan Nugraha)

\section{DAFTAR PUSTAKA}

Abidin. Z Z 1993. Dasar-Dasar Pengetahuan tentang Zat Pengatur Tumbuh. Bandung : Angkasa

Anna, Wiwi dan Irnawati. 2010. Uji Kinerja Kitosan-Bentonite Terhadap Logam Berat dan Diazinon Secara Simultan. Jurnal Sains dan Teknologi Kimia Vol 1.No.2 Oktober 2010.Hal 121-134 ISSN 2087-7412.

Atkins PW. 1999. Kimia Fisika jilid II. Kartohadiprodjo II, penerjemah ;Rohhadyan T, editor. Oxford: University Press. Terjemahan dari: Physical Chemistry.

Joshi, P., Rayalu, S. Bansiwal, A., and Juwarkae, A.A., 2007. Plant Soil. 296. 151-158.

Konta, J. 1995. Clay and Man : Clay Raw Materials in the Service of Man. Appl.Clay sci.10.275-335.

Lai,T.M., and Eberl, D.D.1986. Controlled And Rewenable Release of Phosphorous in Soil from mixtures of Phosphate Rock and $\mathrm{NH}_{4} \quad-\quad$ exchange Clinoptilolite,Zeolite.6.129-132.

Las,T. dkk. 2011. Adsorpsi Unsur Pengotor Larutan Natrium Silikat Menggunakan Zeolit Alam Karangnunggal. Valensi Vol. 2 No. 2, Mei 2011 (368-378) ISSN : 19788193.
Mahida, U. N. 1984. Pencemaran Air dan Pemanfaatan Limbah Industri.Jakarta : CV Rajawali.

Nandi, B.K. Goswami.A. dan Purkait, M.K. 2009b. Adsorption haracteristics of Brilliant Green Dye on Kaolin, J. Hazard.Mate.,161, 387-395.

Prihadi,W. 2005. Slow Release Fertilizer Sebagai Dasar Perumusan Sni Pupuk Urea Berpelepasan Diperlambat. Jakarta : BPPT.

Puspitasari, Dyah Pratama. 2006. Adsorpsi Surfaktan Anionik Pada Berbagai pH Menggunakan Karbon Aktif Termodifikasi Zink Klorida.Skripsi. Departemen Kimia Fakultas Matematika Dan Ilmu Pengetahuan Alam Institut Pertanian Bogor: Bogor.

Rifa'i, Miftah . 2013. Kajian Adsorpsi Linear Alkyl Benzene Sulphonate (LAS) dengan Bentonit Alam.Yogyakarta : UIN Sunan Kalijaga.

Sunardi, Yateman Arryanto dan Sutarno.2009. Adsorpsi Asam Giberelin pada Kaolin asal Tatakan, Kalimantan Selatan.Indo.J.Chem , Hal. 373-379.

Tan H. Kim .1982. Dasar-Dasar Kimia Tanah.Diterjemahkan Didiek Hadjar Goenadi. Yogyakarta : UGM Press. 